
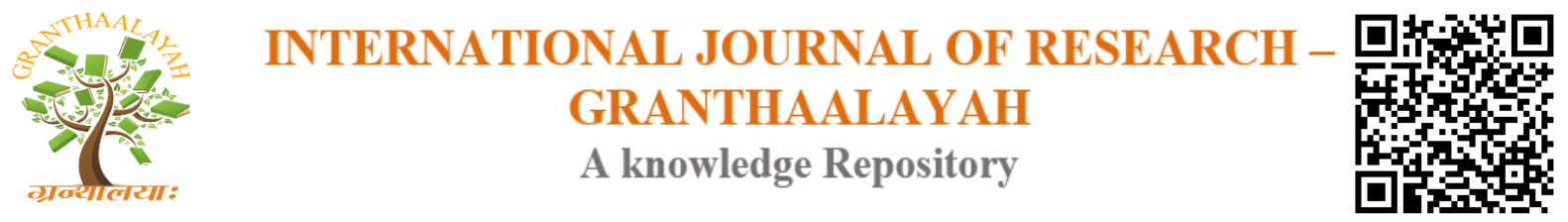

Management

\title{
DYNAMICS OF FOREIGN INSTITUTIONAL INVESTMENTS AND EQUITY RETURNS IN INDIA
}

\author{
Rajdeep Singh ${ }^{* 1}$, Kanwaljeet Singh ${ }^{2}$, Prabhjot Kaur ${ }^{3}$ \\ ${ }^{*}$ Research Scholar, University School of Applied Management, Punjabi University, Patiala, \\ INDIA \\ ${ }^{2}$ Assistant Professor, Sri Aurobindo College of Commerce \& Management, Ludhiana, INDIA \\ ${ }^{3}$ Ex. Assistant Professor, Khalsa College for Women, Ludhiana, INDIA
}

DOI: https://doi.org/10.29121/granthaalayah.v4.i6.2016.2630

\begin{abstract}
India has become a focus point and an attractive hub for foreign investor's post 199. This international flow of capital was facilitated by increased globalization and the growth of information technology which has blurred national borders. Thus FII flows in India have continuously grown in importance post 1991. This paper examines the trend of FII flow in India from 2001 and 2015 and also examines the relationship between FII and the two important barometers of the Indian stock market, i.e., S\&P BSE Sensex and CNX Nifty. The impacts of FII on the proxies for stock market, i.e., Sensex and nifty have been studied by employing simple regression analysis using E-views.
\end{abstract}

Keywords:

FIIs, Indian Stock Market, Regression Analysis.

Cite This Article: Rajdeep Singh, Kanwaljeet Singh, and Prabhjot Kaur, "DYNAMICS OF FOREIGN INSTITUTIONAL INVESTMENTS AND EQUITY RETURNS IN INDIA" International Journal of Research - Granthaalayah, Vol. 4, No. 6 (2016): 1-7.

\section{INTRODUCTION}

Post the New Economic Policy, 1991 India has witnessed a rapid increase in the economic development. This development also resulted in the speedy growth and development of the capital markets in India. Owing to this rapid development supplemented by the growth of capital markets has made India a focus point for the foreign institutional investors. As a result the contributions or investments of these foreign investors have impacted the stock markets in several ways. This international flow of capital was facilitated by increased globalization and the growth of information technology which has blurred national borders. Thus FII flows in India have continuously grown in importance post 1991. 
For a developing country like India capital is one of the necessary pillars for development. Owing to its huge need of capital, the domestic capital falls insufficient and as such there is a need for more and more foreign capital to ensure the country's development. Foreign Capital can enter a country either in the form of Foreign Direct Investment (FDI) or Foreign Institutional Investment (FII). FDI is considered as a long term and a more stable form of investment as compared to FII's. FII changes take place rapidly and are relatively short term investments. Therefore FII inflows and outflows have emerged as movers and shakers of Indian Stock Market. This paper examines the trend of FII flow in India from 2001 and 2015 and also examines the relationship between FII and the two important barometers of the Indian stock market, i.e., S\&P BSE Sensex and CNX Nifty.

The introduction section is followed by a brief review of literature in the second section. The third section discusses the research methodology employed and the fourth section deals with the analysis and findings followed by a section on conclusion in the end.

\section{REVIEW OF LITERATURE}

(Mohanasundaram, 2015) in his study used Correlation \& Autoregressive Distribution Lag and revealed that FII flows are having positive relationship with Exchange Rate, Producer Price Index of USA, Return on S\&P 500, Return on Nifty and market capitalization of NSE. But FII's have a negative relationship with Wholesale Price Index of India.

(Bashir Ahmad Joo, 2014) in his study considered monthly time series on NIFTY, SENSEX and FII's activity for a period of 15 years from January, 1999 to December, 2013 . ADF unit root test and GAARCH model was used to examine the impact of FII's on volatility in Indian stock market and the results revealed the presence of a statistically significant influence on volatility of NIFTY and SENSEX.

(Kumar, 2014) in their study had collected the yearly closing stock of NSE \& BSE for ten years (2003-2013). A high correlation $(r=0.786)$ was found between foreign institutional investments and the stock index of the Indian market which indicates a close relationship between the two.

(Dr. Syed Tabassum Sultana, 2012) while studying the impact of FDI \& FII on Indian stock market considered the data from 2001-2011 and took sensex and nifty as proxies for stock market performance. Statistical techniques such as correlation and multiple regression was used and it was found that there is a positive impact of FDI \& FII on Indian stock market.

(Loomba, 2012) in his study used daily data on BSE Sensex and FII activity from $1^{\text {st }}$ January 2001 to $31^{\text {st }}$ December 2011 and observed that there was a significant positive correlation between FII activity and effects on Indian capital markets.

(Ashis Garg, 2011) in their study utilized the daily data on sensex, FII flow and related variables from the period January 1986 to December 2007. They used regression time series model and GAARCH model for determining the impact of foreign institutional investors on share market return and the results highlighted that volatility of Indian stock market as well as its return has declined after opening the stock market for foreign institutional investors. 
(Anand Bansal, 2009) in their study highlighted that there has been no significant change in the Indian stock market average returns after the country opened itself to foreign institutional investors. However volatility has been significantly reduced after India unlocked its stock market to foreign investors.

(Trivedi \& Nair,2005) in their study examined the volume of foreign investment and profit booking in Indian stock market and found out that due to huge amount of funds invested by foreign institutional investors sometimes they play as market makers and book their gains. Therefore, there exists a relationship between foreign institutional investments and equity stock returns.

(Mohan, 2005) highlighted that mutual funds have been replaced by foreign institutional investors in the equity market. The shareholding of foreign institutional investors in sensex companies is huge and thus can easily move the market. Variations in foreign institutional investments pose difficulty in management of money supply and the exchange rate.

(Bushee, 1998) in his paper titled, "The Influence of Institutional Investors on Myopic R\&D Investment Behaviour" found out that institutional investors who have large ownership, have high portfolio turnover and engage in momentum trading exerts a pressure on managers to reduce investments on $\mathrm{R} \& \mathrm{D}$ so as to enhance short term earnings.

\section{RESEARCH METHODOLOGY}

\subsection{OBJECTIVES OF THE STUDY}

- To study the trends of Foreign Institutional Investors in Indian capital markets from 20012015.

- To study the impact of foreign institutional investors on Indian stock market from 20012015.

\subsection{HYPOTHESIS}

$\mathbf{H}_{\mathbf{0 1}}$ : There is no significant impact of foreign institutional investments on Indian Stock Market from 2001-2015

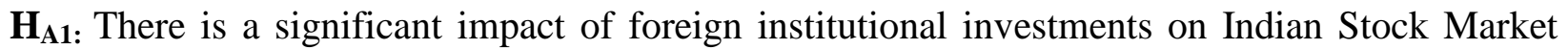
from 2001-2015.

\subsection{DATACOLLECTION}

The entire study is based on secondary data. The required data for this study has been collected from the Reserve Bank of India database, "Handbook of Statistics on Indian economy".

\subsection{SCOPE OF THE RESEARCH}

The study aims to analyze the trend of foreign institutional investments from the period 2001 to 2015. The study will also lay its focus on identifying the possible impact of FII's in the Indian 
Stock Market. In order to understand this impact SENSEX and NIFTY has been used as proxies for the Indian stock market. Monthly data for Net FII, S\&P BSE Sensex and CNX Nifty was taken for the analysis.

\subsection{MODEL BUILDING}

In order to study the impact of foreign institutional investments on Indian stock markets two models were framed and fitted. In model 1 FII is the independent variable and SENSEX is the dependent variable. In model 2 FII is the independent variable and NIFTY is the dependent variable. The models are depicted as follows:

BSE SENSEX $=\mathrm{a}+\mathrm{b}(\mathrm{FII})$

$\mathrm{S} \& \mathrm{P}$ CNX NIFTY $=\mathrm{A}+\mathrm{B}(\mathrm{FII})$

\section{ANALYSIS AND FINDINGS (Derived from Table 1)}

Table 1: Foreign Institutional Investments from 2001-2015

\begin{tabular}{|c|c|c|}
\hline YEAR & $\begin{array}{l}\text { FOREIGN } \\
\text { INVESTMENT } \\
\text { (FII in crores) }\end{array}$ & INSTITUTIONAL \\
\hline 2001 & 13294.7 & \\
\hline 2002 & 3627.23 & \\
\hline 2003 & $29,953.20$ & \\
\hline 2004 & $38,688.40$ & \\
\hline 2005 & $45,825.60$ & \\
\hline 2006 & $31,281.08$ & \\
\hline 2007 & $70,940.05$ & \\
\hline 2008 & $-53,051.70$ & \\
\hline 2009 & $85,367.60$ & \\
\hline 2010 & $140,497.20$ & \\
\hline 2011 & -3642.4 & \\
\hline 2012 & $130,146.80$ & \\
\hline 2013 & $112,381.60$ & \\
\hline 2014 & 98177.9 & \\
\hline 2015 & 13055.57 & \\
\hline
\end{tabular}




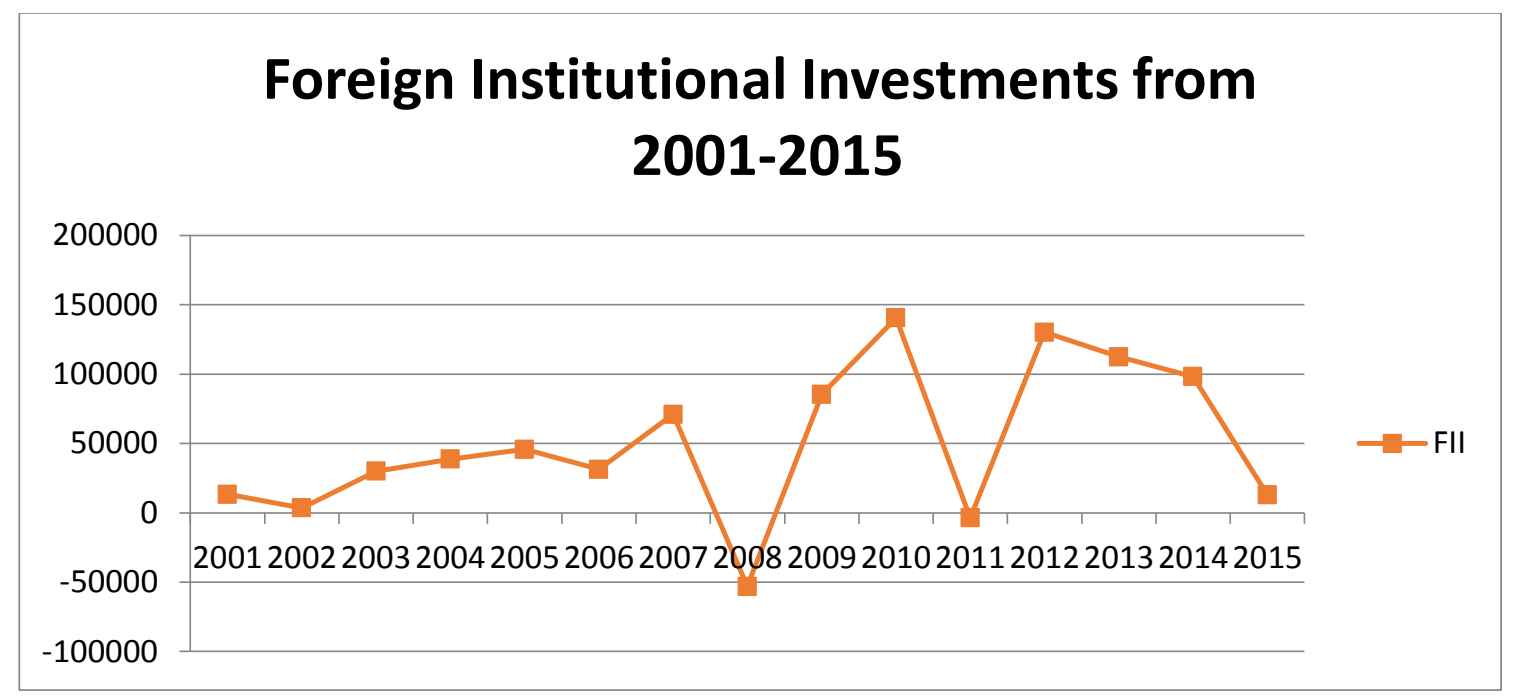

Figure 1: Trend Analysis of FII from 2001-2015

From the above table and graph we can infer that FII's increased from Rs. 13294.7 crores in 2001 to Rs. 70940.05 crores in 2007. The CAGR of FII's in this period was $72.27 \%$. Within this period FII's declined twice from its earlier position, once in 2002 and then in 2006. The major decline that came in FII's was in the year 2008 where it declined to net outflows of Rs. 53051.70 crores ( by $-174 \%$ from previous year). This decline was a spillover effect of the housing loan bubble that started from the USA's economy. Post 2008 the FII's revived rapidly and increased to Rs. 1,40,497.20 crores till 2010. Post 2010 the FII's again declined heavily and reached to Net outflows of Rs. 3642 crores due to the European debt crisis in which the FII's pulled back their investments. The FII's have been declining steadily post 2012 and were only Rs. 13055.17 crores in 2015.

Table 2: Regression Results of impact of FII on SENSEX (Model1)

Dependent Variable: SENSEX

Method: Least Squares

Date: 05/14/16 Time: 12:23

Sample: 2001M01 2015M12

Included observations: 180

\begin{tabular}{lllll}
\hline \hline Variable & Coefficient & Std. Error & t-Statistic & Prob. \\
\hline \hline \multicolumn{1}{c}{ C } & 12662.45 & 622.5808 & 20.33864 & 0.0000 \\
\multicolumn{1}{c}{ NET_FII } & 0.240152 & 0.068679 & 3.496731 & 0.0006 \\
\hline \hline R-squared & 0.064276 & Mean dependent var & 13671.81 \\
Adjusted R-squared & 0.059020 & S.D. dependent var & 7629.298 \\
S.E. of regression & 7400.735 & Akaike info criterion & 20.66760 \\
Sum squared resid & $9.75 E+09$ & Schwarz criterion & 20.70307 \\
Log likelihood & -1858.084 & Hannan-Quinn criter. & 20.68198 \\
F-statistic & 12.22713 & Durbin-Watson stat & 0.063234 \\
Prob(F-statistic) & 0.000595 & & \\
\hline \hline
\end{tabular}


Table 2 above shows the results of impact of FII on SENSEX. The $p$ values of both the coefficient and FII are less than 0.05. Therefore both of them are relevant in our proposed regression model. Net FII contributes about $5.9 \%$ in explaining the dependent variable, i.e., SENSEX in this case. The final regression model with SENSEX as the dependent variable and Net FII as the independent variable has been shown below.

\section{SENSEX $=12662.45+0.240152$ NET_FII}

In the above equation the coefficient is 12662.45 . This means that when Net FII is zero the value of SENSEX will be 12662.45. When Net FII increases by 1 unit, the rate of change in SENSEX will be 0.240152 .

Table 3: Regression Results of impact of FII on Nifty (Model 2)

\begin{tabular}{|c|c|c|c|c|}
\hline \multicolumn{5}{|c|}{$\begin{array}{l}\text { Dependent Variable: NIFTY } \\
\text { Method: Least Squares } \\
\text { Date: 05/14/16 Time: 12:26 } \\
\text { Sample: 2001M01 2015M12 } \\
\text { Included observations: } 180\end{array}$} \\
\hline Variable & Coefficient & Std. Error & t-Statistic & Prob. \\
\hline $\mathrm{C}$ & 3819.372 & 185.0074 & 20.64442 & 0.0000 \\
\hline NET_FII & 0.071699 & 0.020409 & 3.513152 & 0.0006 \\
\hline R-squared & 0.064842 & \multirow{7}{*}{\multicolumn{2}{|c|}{$\begin{array}{l}\text { Mean dependent var } \\
\text { S.D. dependent var } \\
\text { Akaike info criterion } \\
\text { Schwarz criterion } \\
\text { Hannan-Quinn criter. } \\
\text { Durbin-Watson stat }\end{array}$}} & 4120.725 \\
\hline Adjusted R-squared & 0.059589 & & & 2267.824 \\
\hline S.E. of regression & 2199.218 & & & 18.24064 \\
\hline Sum squared resid & $8.61 \mathrm{E}+08$ & & & 18.27612 \\
\hline Log likelihood & -1639.658 & & & 18.25502 \\
\hline F-statistic & 12.34223 & & & 0.062403 \\
\hline $\operatorname{Prob}($ F-statistic) & 0.000561 & & & \\
\hline
\end{tabular}

Table 3 above shows the results of impact of FII on CNX NIFTY. The p values of both the coefficient and FII are less than 0.05. Therefore both of them are relevant in our proposed regression model. Net FII contributes about $5.9 \%$ in explaining the dependent variable, i.e., CNX Nifty in this case. The final regression model with NIFTY as the dependent variable and Net FII as the independent variable has been shown below.

$$
\text { NIFTY }=3819.37155016+0.0716992730891 * \text { NET_FII }
$$

In the above equation the coefficient is 3819.372. This means that when Net FII is zero the value of NIFTY will be 3819.372. When Net FII increases by 1 unit, the rate of change in SENSEX will be 0.071699 . 


\section{CONCLUSION}

On the whole we can say that Net FII in the country has increased in the country since 2001. This could be attributed to the aftereffects of the liberalization and globalization policy adopted in the New Economic Policy of 1991. However there were certain periods within the 15 year tenure from 2001-2015 when there was huge fall in the Net FII in the country. The two important downfall periods were 2008 and 2011. These two years of downfall in FII were the results of the US housing bubble and the Euro debt crisis respectively. The study also revealed that Net FII had a significant impact on the proxies of the Indian stock market, i.e, SENSEX and NIFTY. In both the cases Net FII contributed about $5.9 \%$ in the explanation of these two dependent variables. For a developing country like India capital is one of the necessary pillars for development. Owing to its huge need of capital, the domestic capital falls insufficient and as such there is a need for more and more foreign capital to ensure the country's development.

\section{REFERENCES}

[1] Anand Bansal, J. P. (2009). Foreign Institutional Investors Impact on Stock Prices in India. Journal of Academics Research in Economics, 181-189.

[2] Ashis Garg, B. B. (2011). Impact of the Foreign Institutional Investments on Stock Market: Evidence from India. Indian Economic Review, 303-322.

[3] Bashir Ahmad Joo, Z. A. (2014). Impact of FIIs Investment on Volatility of Indian Stock Market: An Empirical Investigation. Journal of Business \& Economic Policy.

[4] Bushee, B. J. (1998). The Influence of Institutional Investors on Myopic R\&D Investment Behavior. The Accounting Review, 305-333.

[5] Dr. Syed Tabassum Sultana, P. S. (2012). Impact of Flow of FDI \& FII on Indian Stock. Finance Research, 4-10.

[6] Kumar, A. A. (2014). Impact of FII on Stock Market in India. Global Journal of Finance and Management. , 6, 765-770.

[7] Loomba, J. (2012). DO FIIS IMPACT VOLATILITY OF INDIAN STOCK MARKET? International Journal of Marketing, Financial Services \& Management Research, 80-93.

[8] Mohan, T. T. (2005). Taking Stock of Foreign Institutional Investors. Economic and Political Weekly, 2395-2399.

[9] Mohanasundaram, T. (2015). MACROECONOMIC DYNAMICS OF FOREIGN INSTITUTIONAL. International Journal of Management Research \& Review, 39-47. 